\title{
AN ASSAY OF BORDETELLA PERTUSSIS ADHESION TO TISSUE-CULTURE CELLS
}

\author{
K. REDHEAD \\ National Institute for Biological Standards and Control, Bacterial Products Division, \\ Holly Hill, Hampstead, London NW3 6RB
}

\begin{abstract}
SUMMARY. The ability of Bordetella pertussis to bind to cell surfaces was determined with a simple, accurate, reproducible assay measuring the adhesion of radiolabelled bacteria to monolayers of HeLa cells. The rate of adhesion was approximately linear with time for at least $1 \mathrm{~h}$. Viable and radioactivity counts of bound bacteria correlated well. Bacteria grown in the avirulent $\mathrm{C}$-mode were markedly less adhesive than virulent X-mode cells. Reductions in the level of attachment after treatment of bacteria with preparations of specific immunoglobulin suggest that adhesion of $B$. pertussis depends upon specific mechanisms involving filamentous haemagglutinin and the agglutinogens.
\end{abstract}

\section{INTRODUCTION}

The development of a new effective whooping-cough vaccine would be aided by a clear understanding of the pathogenic mechanisms of Bordetella pertussis. The ability of $B$. pertussis to adhere to cell surfaces has been proposed as one important factor associated with the virulence of the organism (Matsuyama, 1977; Sato et al., 1979). This property has been examined by various methods including haemagglutination tests (Keogh and North, 1948), microscopic observations of bacteria attached to tissue-culture cells (Holt, 1972; Sato et al., 1981), microscopic and viable counts of bacteria bound to rabbit, hamster or chick tracheal organ cultures (Iida and Ajiki, 1974; Collier, Peterson and Baseman, 1977; Matsuyama, 1977) and the assessment of bacterial adhesion to mouse lungs by radiolabelling techniques (Burns and Freer, 1982). However, attempts to quantify these methods are prone to difficulties with enumeration, contamination or uneven distribution of surface cell types, which may interfere with accurate and reproducible measurements of bacterial adhesion. The use of a radiolabelling procedure to quantify the attachment of bacteria to uniform areas of tissue-culture cells offers a rapid, simple and accurate system for the measurement of adhesion, provided controls are incorporated to exclude artefacts (Marchase, Vosbeck and Roth, 1976). Such an assay may provide a useful in-vitro model to investigate the bacterial components involved in adhesion.

This paper describes an in-vitro assay for measuring the attachment of radiolabelled $B$. pertussis to HeLa-cell monolayers. The assay was used to compare the 
adhesive ability of virulent (X-mode) $B$. pertussis with the growth modulated C-mode organism, which lacks several $\mathrm{X}$-mode properties including virulence. It was also possible to determine the effects of immunoglobulins raised against specific whole-cell vaccines of $B$. pertussis and the purified filamentous haemagglutinin antigen (FHA) on the adhesion of virulent $B$. pertussis cells.

\section{MATERIALS AND METHODS}

Bacterial strains and growth conditions. B. pertussis strains Wellcome 28 (W28) and Tohama were maintained in $5 \% \mathrm{v} / \mathrm{v}$ glycerol- $1 \% \mathrm{w} / \mathrm{v}$ casamino acids in ampoules held in liquid nitrogen. Cells from ampoules were grown in 250-ml Erlenmeyer flasks with $100 \mathrm{ml}$ of medium per flask, at $35^{\circ} \mathrm{C}$ either static for 5 days or agitated on an orbital incubator for 3 days. The standard medium of Stainer and Scholte (1971) was used to grow cultures in the X mode; C-mode organisms were obtained by a modification of this medium in which the $\mathrm{NaCl}$ was replaced by an equimolar amount of $\mathrm{MgSO}_{4} .7 \mathrm{H}_{2} \mathrm{O}$ (Parton and Wardlaw, 1975). Cells were harvested by centrifugation and were stored at $-30^{\circ} \mathrm{C}$ until required.

The serological type of statically grown W28 and Tohama strains was confirmed in slide agglutination tests with Wellcome monospecific horse antisera to agglutinogens 1,2 and 3 (Wellcome Reagents Ltd, Beckenham) (Preston, 1963).

Tissue culture. HeLa-cell cultures were maintained in 150-ml medicine bottles in 199 tissue culture medium (Morgan, Morton and Parker, 1950) with 10\% tryptose-phosphate broth (Difco) and $10 \%$ calf serum in a humidified atmosphere at $37^{\circ} \mathrm{C}$. The cells were subcultured every 7 days; they were dissociated with trypsin (Difco) $0.2 \% \mathrm{w} / \mathrm{v}$ in saline A solution $(\mathrm{NaCl} 0.8 \% \mathrm{w} / \mathrm{v}$, $\mathrm{KCl} 0.04 \% \mathrm{w} / \mathrm{v}$, glucose $0.1 \% \mathrm{w} / \mathrm{v}$ ).

Preparation of immunoglobulins. Vaccines of W28 and Tohama X-mode and C-mode cells were prepared by resuspending harvested static-grown cells in phosphate-buffered saline (PBS) and heating at $56^{\circ} \mathrm{C}$ for $30 \mathrm{~min}$. The cells were collected by centrifugation, resuspended in the same volume of fresh PBS containing thiomersal $0.01 \% \mathrm{w} / \mathrm{v}$ as a preservative, and stored at $4{ }^{\circ} \mathrm{C}$ for at least 3 months before use. FHA purified from supernates of 5-day static cultures of $B$. pertussis (Robinson, Hawkins and Irons, 1981), kindly provided by Dr A. Robinson, was diluted in PBS and used for the production of anti-FHA sera.

$\mathrm{Balb} / \mathrm{C}$ mice 8-10-weeks-old received two intraperitoneal injections of the vaccine preparations, each containing $C .1 .5 \times 10^{9}$ cells, or $5 \mu \mathrm{g}$ of FHA, in $0.5 \mathrm{ml}$ of PBS, 14 days apart. The mice were bled from the heart, under chloroform anaesthesia, 6 days after the second injection and the sera were separated and pooled. Control sera were obtained from mice which received PBS only.

The agglutination titres of the antisera were tested as described by Evans and Perkins (1953). Cultures of $B$. pertussis strain W28 X-mode, grown statically, were harvested by centrifugation and resuspended in PBS to a concentration of $3 \times 10^{10}$ organisms $/ \mathrm{ml}$. Serum titrations were made by adding $0.3 \mathrm{ml}$ of this bacterial suspension to $0.3 \mathrm{ml}$ of each of a series of twofold dilutions of serum in Dreyer's tubes. The tubes were mixed, incubated at $37^{\circ} \mathrm{C}$ in a water bath for $1 \mathrm{~h}$ and read after a further $18 \mathrm{~h}$ at room temperature. The end-point was taken as the highest dilution that gave definite clumping.

The immunoglobulin fractions of the control serum and of the antisera were prepared by the method of Harboe and Ingild (1973) omitting the diethylaminoethyl-sephadex chromatography step. The immunoglobulin preparations were stored at $-20^{\circ} \mathrm{C}$ at protein concentrations of 20 $\mathrm{mg} / \mathrm{ml}$.

Detection of immunoglobulin responses to B. pertussis antigens. Crude outer-membrane-protein (OMP) fractions from $B$. pertussis prepared by sonic disruption and Triton X-100 (Sigma) extraction, as previously described (Redhead, 1983), and purified FHA were subjected to sodium dodecyl sulphate-polyacrylamide gel electrophoresis (SDS-PAGE) in slab gels $(1.5 \mathrm{~mm}$ thick) containing acrylamide $11 \%$, bis-acrylamide $0.2 \%$ and SDS $0.2 \%$ prepared as described by Lugtenberg et al. (1975). The amount of protein applied to each lane was $200 \mu \mathrm{g}$ for OMP fractions and $20 \mu \mathrm{g}$ for FHA. After electrophoresis, the lane strips were cut out and the proteins electrophoretically transferred (Johnstone and Thorpe, 1982) to nitrocellulose sheets (Schleicher 
and Schüll, $0 \cdot 45-\mu \mathrm{m}$ pore size, Dassel, West Germany) by the electroblot system EC-420 (EC apparatus, St Petersburg, FL, USA). The nitrocellulose sheets were agitated in PBS containing azide $0.02 \% \mathrm{w} / \mathrm{v}$ and bovine haemoglobin $3 \% \mathrm{w} / \mathrm{v}(\mathrm{Hb}-\mathrm{PBS})$ for $2 \mathrm{~h}$ at room temperature and exposed to immunoglobulin preparations, at a concentration of $0.5 \mathrm{mg}$ of protein per lane strip diluted in Hb-PBS, overnight. After washing with fresh Hb-PBS any antigen-antibody complexes present were labelled by shaking for $3 \mathrm{~h}$ with ${ }^{125} \mathrm{I}$-labelled goat anti-immunoglobulin (c. $10^{6} \mathrm{cpm} /$ lane strip). The sheets were washed in PBS plus azide, dried in an oven at $45^{\circ} \mathrm{C}$, then autoradiographed for up to 7 days with Kodak X-omat S film in Protex X-ray cassettes. Quantitative estimates of the relative amounts of antibodies in immunoglobulin preparations were based on visual comparisons of the intensities of the autoradiograms of samples that were derived from the same gel and electrophoretically transferred and processed at the same time.

Radiolabelling of bacteria. Radiolabelled bacteria $\left(c .5 \times 10^{-5} \mathrm{cpm} /\right.$ bacterium) were obtained by inoculating $10 \mathrm{ml}$ of $\mathrm{X}$ - or $\mathrm{C}$-mode growth medium, containing $10 \mu \mathrm{Ci}$ of inorganic ${ }^{32} \mathrm{P}$, with sufficient bacteria from 2-day-old agitated cultures to give an initial optical density (OD) of $0 \cdot 25$ at $623 \mathrm{~nm}$ (MSE, Vitatron). After static incubation for $24 \mathrm{~h}$ at $35^{\circ} \mathrm{C}$, the bacteria were harvested by centrifugation, washed thrice with 199 medium and their concentration adjusted photometrically to an OD of 0.4 at $623 \mathrm{~nm}\left(c .2 \times 10^{9}\right.$ bacteria $\left./ \mathrm{ml}\right)$ for use in the adhesion assay. Samples $(0.5$ $\mathrm{ml}$ ) of the suspensions at this stage were mixed with $4 \mathrm{ml}$ of Beckman EP scintillant fluid and counted on a Packard Tri-carb liquid scintillation counter. To assess the amount of radioactivity associated with the bacteria, the radioactivity remaining in the supernate after centrifugation at $4000 \mathrm{~g}$ for $15 \mathrm{~min}$ was subtracted from the total radioactivity of an equal volume of the bacterial suspension.

Bacterial adhesion assay. The adhesion assay was based on that described by Vosbeck and Huber (1982) for the assessment of adhesion of strains of $E$. coli. HeLa-cell monolayers were prepared in Flow Linbro Spacesaver multiwell dishes $\left(2 \mathrm{~cm}^{2}\right.$ each $)$ with $1.5 \times 10^{5}$ cells $/ \mathrm{ml}$ from a confluent culture as inoculum in $1.5 \mathrm{ml}$ of 199 tisue culture medium plus tryptose-phosphate broth and calf serum. Confluent cell layers were produced after growth for $18-24 \mathrm{~h}$ at $37^{\circ} \mathrm{C}$. They were washed twice with 199 medium immediately before use, then $0.5 \mathrm{ml}$ of 199 medium containing additions at twice the normal concentration was added to each well together with 0.5 $\mathrm{ml}$ of the radiolabelled bacterial suspension to give a final volume of $1.0 \mathrm{ml}$ and a bacterial concentration of $c .10^{9}$ organisms $/ \mathrm{ml}$. The monolayers were shaken at $120 \mathrm{rpm}$ on an orbital shaker at $37^{\circ} \mathrm{C}$. After specified incubation times, unbound bacteria were removed by washing thrice with $1.0 \mathrm{ml}$ of warm $\left(37^{\circ} \mathrm{C}\right) 199$ medium with additions as above. The washed monolayers were examined microscopically for any cytotoxic effects, solubilised by the addition of $1.5 \mathrm{ml}$ of a $0.5 \% \mathrm{w} / \mathrm{v}$ aqueous solution of SDS, and incubated on an orbital shaker $(120 \mathrm{rpm})$ for $3 \mathrm{~h}$ at $37^{\circ} \mathrm{C}$. Portions $(0.75 \mathrm{ml})$ of the solubilised mixture were counted by liquid scintillation counting. Results were calculated as percentages of the radioactivity associated with bacteria bound to the monolayers and expressed as the percentage of bacteria bound per monolayer. All assays were performed in triplicate.

The non-specific binding of labelled bacteria to exposed plastic surfaces was determined by performing an adhesion assay as described with tissue-culture wells which had been incubated overnight with 199 medium plus additions but devoid of tissue-culture cells. To assess the contribution of non-specific binding of radioactivity unassociated with bacteria to the observed adhesion values, a washed labelled bacterial suspension was split. One part was used in a standard adhesion assay with an incubation time of $1 \mathrm{~h}$. The other part was shaken $(120 \mathrm{rpm})$ at $37^{\circ} \mathrm{C}$ for $1 \mathrm{~h}$ and the bacteria were removed by centrifugation $(4000 \mathrm{~g}$ for $15 \mathrm{~min}$ ). The resulting supernate was incubated with cell monolayers in standard assay conditions for $1 \mathrm{~h}$ and the amount of radioactivity associated with the monolayers determined. The result represented the amount of free radioactivity, i.e., radioactivity present in the bacterial suspension but unassociated with the bacteria, together with radioactivity leaked from the bacteria, which was non-specifically adsorbed by the monolayers in a normal adhesion assay.

Counts of viable bacteria. To estimate the number of attached viable bacteria, cell monolayers were dissociated by incubation with PBS containing trypsin $0.2 \% \mathrm{w} / \mathrm{v}$ and the HeLa cells lysed by 10 -fold dilution with distilled water. Serial dilutions with PBS of the resulting suspensions were spread on Bordet-Gengou Agar (Oxoid) plates and the colonies formed after incubation for $48 \mathrm{~h}$ at $35^{\circ} \mathrm{C}$ were counted. 


\section{RESULTS}

Comparison of adhesion measured by radioactivity and viable counts

The adhesion of $B$. pertussis W28 X-mode cells to monolayers of HeLa cells was approximately linear with time for up to $1 \mathrm{~h}$, as measured by radioactivity counts and by counts of bound viable bacteria (fig. 1). Both assay techniques showed that bacterial attachment approached saturation after $3 \mathrm{~h}$. With incubation times of up to $3 \mathrm{~h}$ the results of the radioactivity counts varied by $<10 \%$ of the mean value in the triplicate assays. The viable counts showed slightly greater variation throughout the time course

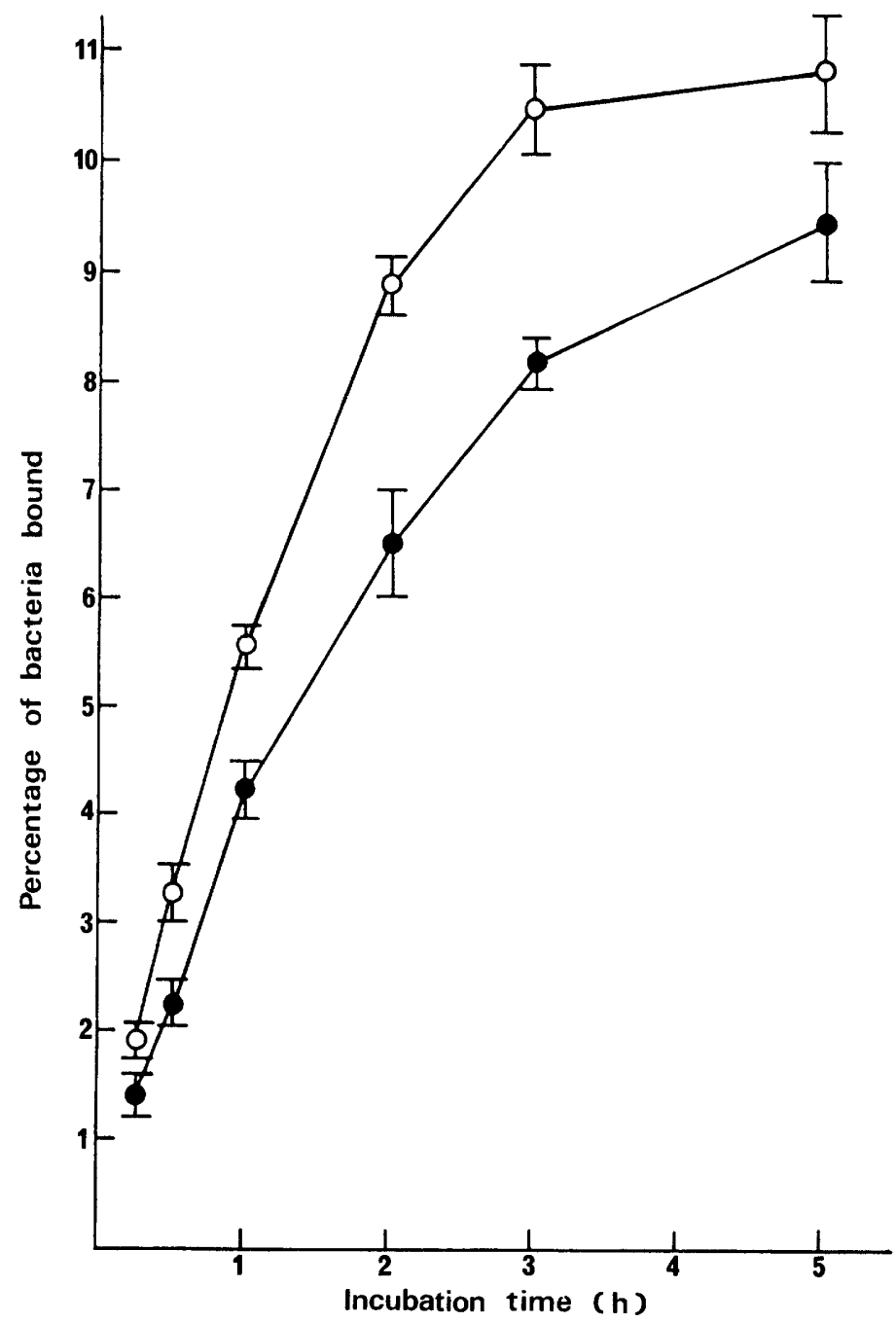

FIG. 1.-Correlation of B. pertussis (W28 X-mode) adhesion to HeLa cell monolayers measured by radioactivity, $o$; and by the number of viable bacteria bound, $\bullet$. The means and standard deviations of three assays are shown. 
of the assay and after $5 \mathrm{~h}$ the results with both methods varied by $>10 \%$. Viable counts gave consistently lower values for adhesion than radioactivity measurements, up to $2.3 \times 10^{7}$ fewer bacteria bound per monolayer. However, when the percentage of bacteria bound was plotted against time, curves of the number of bound bacteria obtained from radioactivity counts closely paralleled curves obtained from counts of attached viable bacteria (fig. 1).

The results from the radioactivity counting assay varied by $<15 \%$ from day to day. The adhesion of radiolabelled bacteria to plastic culture wells devoid of HeLa cells was always $<5 \%$ of the values observed with cell monolayers. Similarly, adsorption during the assay of radioactivity not associated with bacteria was $<5 \%$. These effects did not, therefore, significantly interfere with the interpretation of the results.

Microscopic examination of the cell monolayers after adhesion of bacteria showed the layers to be confluent and without signs of damage with the exception that after incubation for $5 \mathrm{~h}$ with the $B$. pertussis suspensions, very small numbers of apparently dead HeLa cells were observed.

\section{Effect of growth modulation on adhesion}

$B$. pertussis strains W28 and Tohama grown in the virulent X-mode showed similar levels of adhesion, measured by radioactivity counts, after incubation with HeLa-cell monolayers for $1 \mathrm{~h}(5 \cdot 7-6 \cdot 2 \%$ of bacteria bound) (fig. 2a). Significantly lower levels of bacterial attachment were found when the avirulent $\mathrm{C}$-modes of both strains were assayed after incubation for $1 \mathrm{~h}(2 \cdot 3-2 \cdot 5 \%$ of bacteria bound). This marked reduction in adhesion with the change from $\mathrm{X}$ to $\mathrm{C}$ mode was still apparent, with both strains, after incubation for $2 \mathrm{~h}$ with cell monolayers (fig. 2b). Control experiments showed that assay variations and non-specific binding of radioactivity were within acceptable limits.

\section{Effect of immunoglobulins on adhesion}

The X-mode cells of strains W28 and Tohama were found to possess type agglutinogens 1, 2, 3 and 1,2 respectively, whereas the C-mode cells were devoid of these agglutinogens. The agglutination titres of the antisera raised in $\mathrm{Balb} / \mathrm{C}$ mice are shown in the table. When tested for antibodies by immunoblotting (fig. 3) the immunoglobulin preparations from antisera to X-mode W28 and Tohama strains showed similar patterns of responses to $B$. pertussis OMPs, although anti-Tohama gave stronger reactions with the higher mol. wt proteins, and both reacted strongly with the purified FHA, which appeared as three major high mol. wt components $\left(136 \times 10^{3}, 114 \times 10^{3}\right.$ and $\left.108 \times 10^{3}\right)$ and a few minor bands in this system. The anti-FHA immunoglobulin preparation gave the strongest reaction with the FHA components, as expected, and no detectable responses to the other OMPs. The anti-W28 C-mode immunoglobulins gave no significant response to FHA nor with the higher mol. wt OMPs.

To examine the effect of the immunoglobulins on the adhesion of $B$. pertussis W28 $\mathrm{X}$-mode bacteria, the radioactivity counting assay was used with one modification. Before addition to the washed cell monolayers the radio-labelled bacterial suspensions were incubated at room temperature for $15 \mathrm{~min}$ in 199 medium containing immunoglobulin preparations at a protein concentration of $1.0 \mathrm{mg} / \mathrm{ml}$. These 


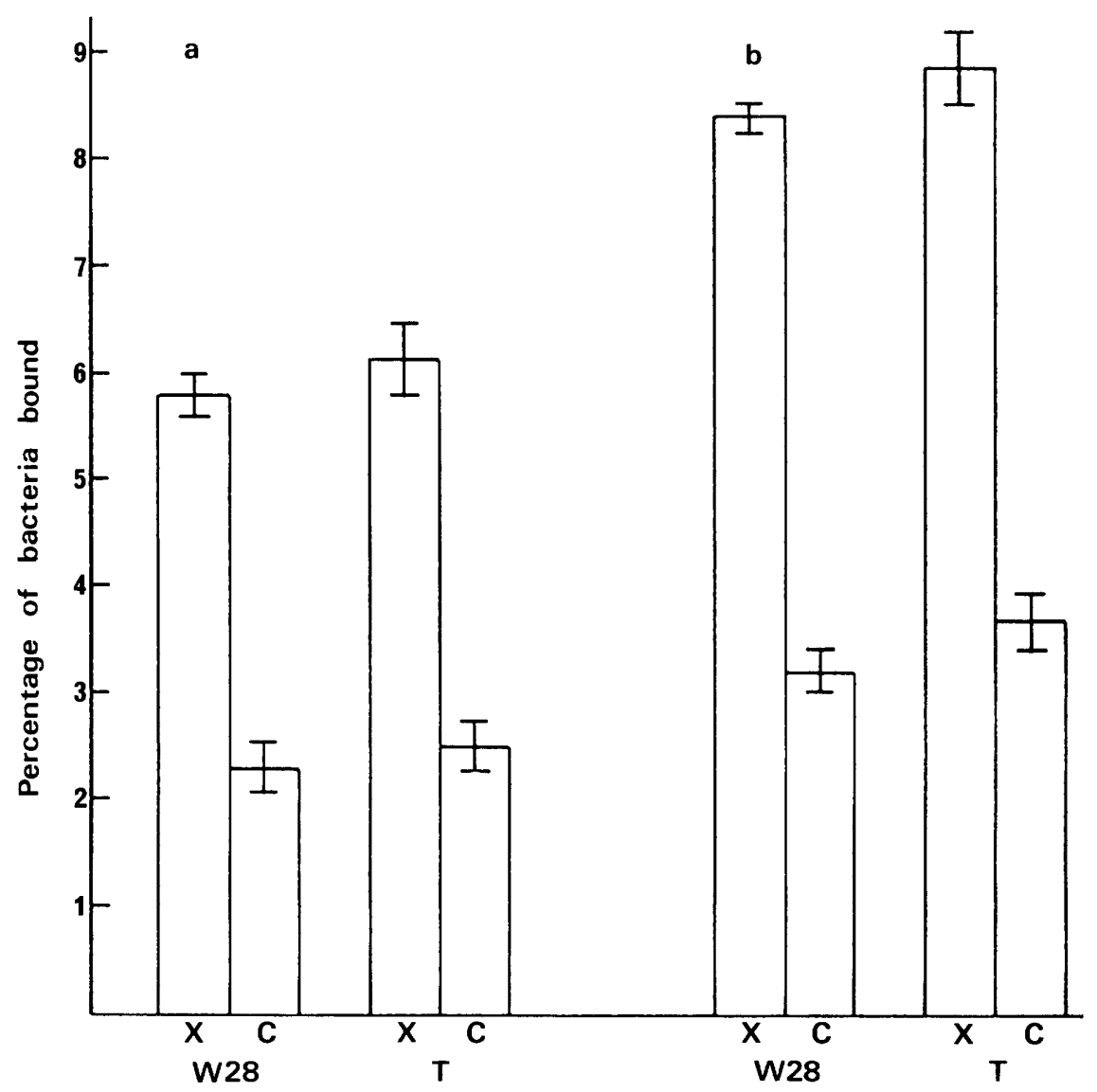

FIG. 2.- Adhesion of $B$. pertussis strains W28 and Tohama (T) X-and C-mode cells; incubation for (a) $1 \mathrm{~h}$ and (b) $2 \mathrm{~h}$ with HeLa cell monolayers. The means and standard deviations of three assays are shown.

TABLE

Agglutination titres of antisera for statically-grown W28 X-mode bacteria

\begin{tabular}{l|r}
\hline \multicolumn{1}{c|}{ Antiserum } & Agglutination titre \\
\hline W28X & 512 \\
W28C & 2 \\
Tohoma X & 512 \\
FHA & 0 \\
PBS (control) & 0 \\
\hline
\end{tabular}

suspensions were then added to the monolayers and incubated for $1 \mathrm{~h}$ at $37^{\circ} \mathrm{C}$ and the percentage of bacteria bound to the HeLa cells assessed as previously described. Adhesion of W28 X-mode bacteria to cell monolayers was markedly reduced when the bacteria were pre-exposed to immunoglobulins raised against FHA or to sera raised against X-mode Tohama cells (fig. 4), which contained anti-FHA and presumably agglutinins 1 and 2. The level of bacterial attachment was lowest after treatment with anti-W28 X-mode immunoglobulins, containing anti-FHA and agglutinins 1, 2 and 3, 


\section{$\begin{array}{llllllll}A & B & C & D & E & F & G & H\end{array}$}

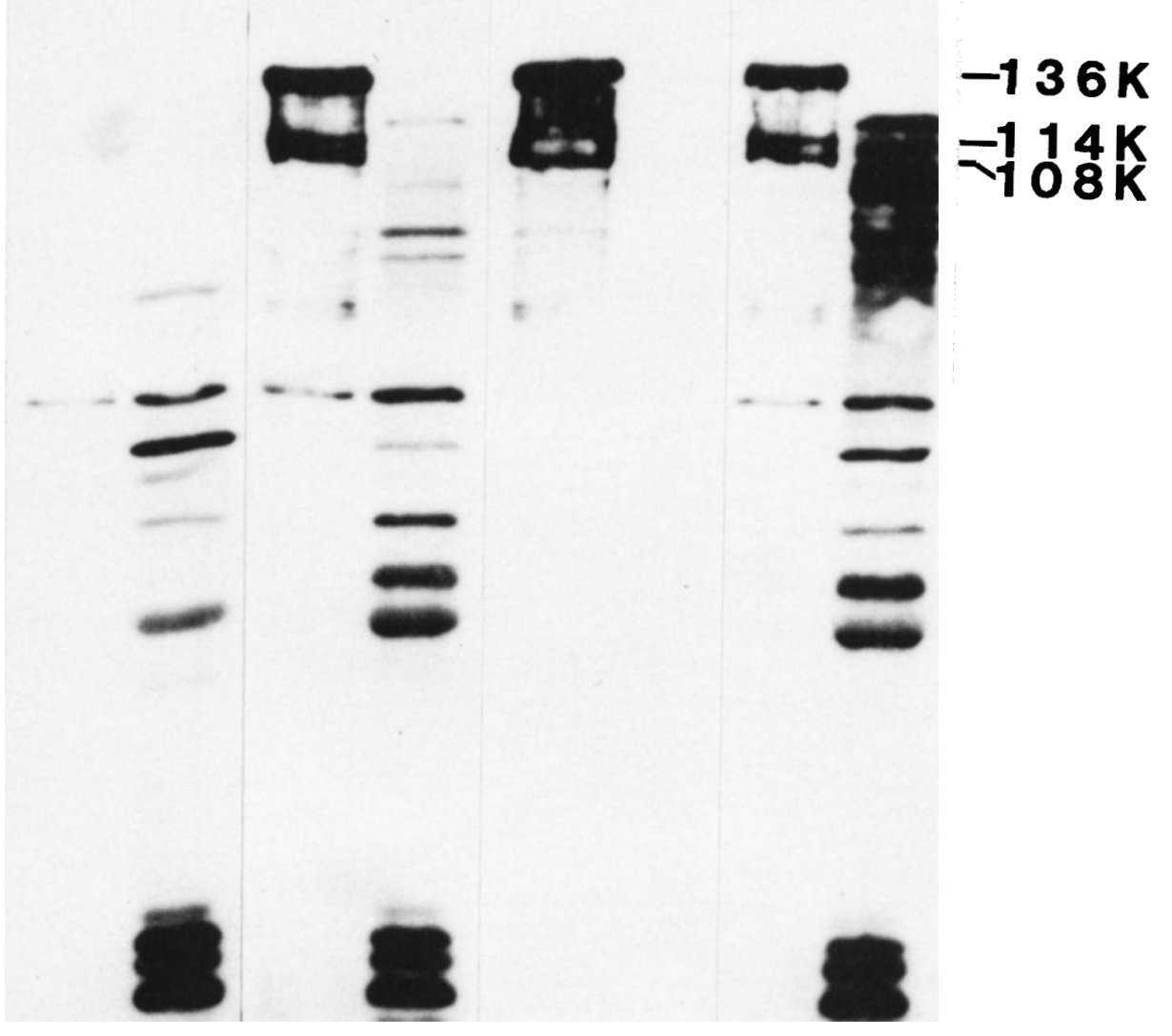

FIG. 3.-Immunoglobulin responses to OMPs of B. pertussis (lanes B, D, F and H) and purified FHA (lanes

$A, C, E$ and $G$ ). Immunoglobulins from sera of mice vaccinated with W28 C-mode vaccine (lanes $A$ and B), W28 X-mode vaccine (lanes C and D), purified FHA (lanes E and F) and Tohama X-mode vaccine (lanes $\mathrm{G}$ and $\mathrm{H}$ ) were examined for antibodies as described in the text. The amount of protein used in the preliminary SDS-PAGE was $200 \mu \mathrm{g} /$ lane of W 28 X-mode OMPs and $20 \mu \mathrm{g} /$ lane of purified FHA.

under which conditions only $0.9 \%$ of the bacteria were bound compared with $5.6 \%$ after treatment with control immunoglobulins (fig. 4). Exposure to anti-W28 C-mode immunoglobulins caused the level of bacterial adhesion to be reduced only to $4.4 \%$. Treatment of X-mode bacteria with control immunoglobulins did not affect attachment, which was at the same level $(5.6 \%)$ as in previous standard assays (figs 1 and 2 ). Microscopic examination of W28 X-mode suspensions after incubation for $75 \mathrm{~min}$ in 199 medium containing immunoglobulins revealed no detectable bacterial agglutination regardless of which vaccine preparations had been used to raise the immunoglobulins.

\section{Discussion}

The assay system described is an accurate and simple method for measuring the adhesion of $\boldsymbol{B}$. pertussis to cells in vitro. The use of radioactivity counting to assess bacterial binding to HeLa-cell monolayers provides reproducible results which 


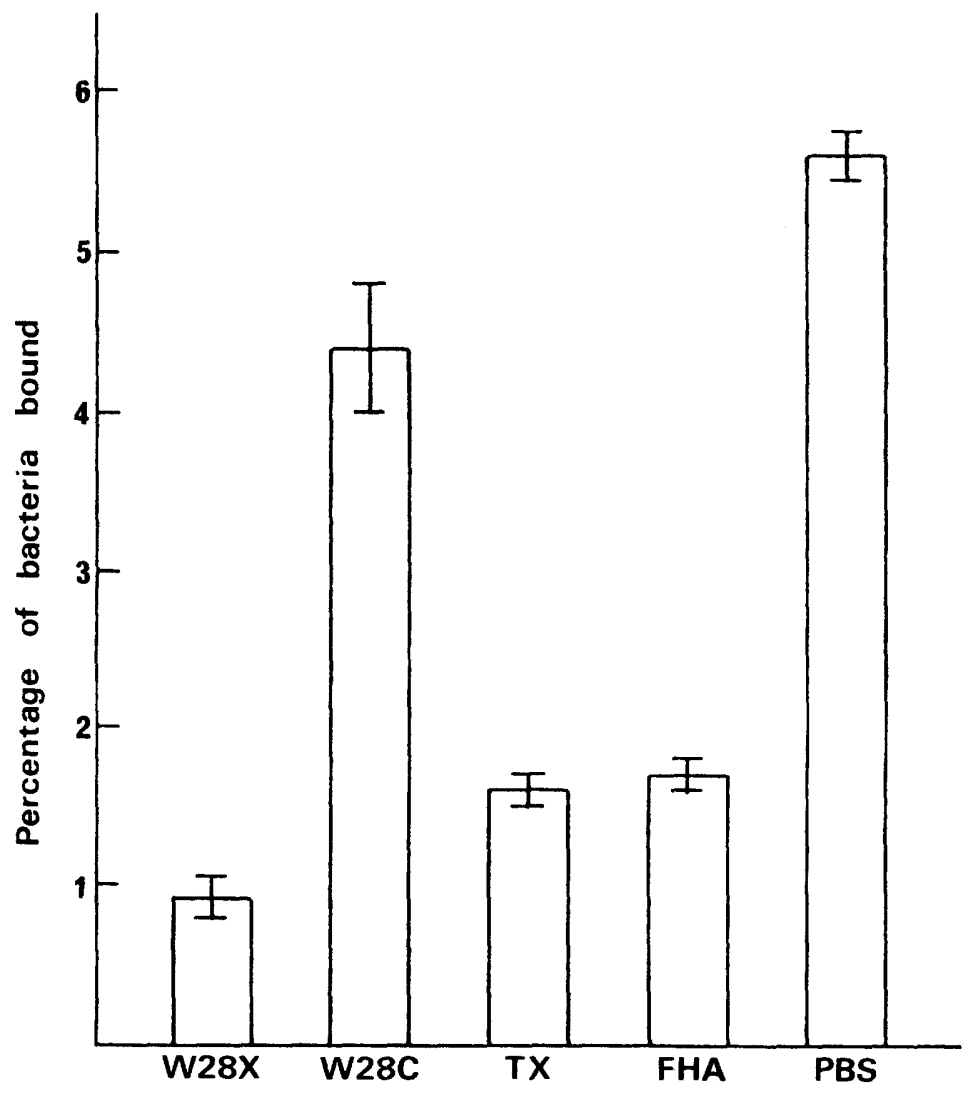

FIG. 4.-Adhesion of $B$. pertussis (W28 X-mode) to HeLa-cell monolayers after incubation with immunoglobulin preparations as described in the text. The means and standard deviations of three assays are shown. The immunoglobulins used were from antisera raised against W28 X-mode (W28X), W28 C-mode (W28C), Tohama X-mode(TX), filamentous haemagglutinin (FHA); PBS = PBS control.

correlate well with viable counts and has the advantages of being more rapid and adaptable. Control experiments have shown that the amount of non-bacterial associated radioactivity bound to the monolayers is negligible and that the attachment of $B$. pertussis to the tissue-culture cells is specific as shown by the low levels of bacterial attachment to exposed plastic culture wells.

The level of bacterial adhesion determined by viable counts was consistently lower than the assessment by radioactivity counts. There are two possible explanations for this phenomenon. Either the treatment of the monolayers prior to their application to the agar counting plates caused a reduction in viability of the bound bacteria, or, where more than one bacterium was attached to a single piece of disrupted HeLa-cell plasma membrane, due to their close proximity; only one colony developed after incubation on Bordet-Gengou agar.

A reduction in the ability of $B$. pertussis to adhere to mouse lung tissue has been reported to coincide with modulation from $X$ to $C$ mode (Burns and Freer, 1982). Although $\mathrm{C}$-mode bacteria were found to be less adhesive than X-mode bacteria when examined in the present assay, the reduction recorded was $c .60 \%$, after incubation for 1 or $2 \mathrm{~h}$, compared with the $80 \%$ decrease in binding observed by Burns and Freer 
(1982). This discrepancy is probably attributable to the different assay systems and strains of $B$. pertussis used. The adherence of X-and C-modes of other strains of $B$. pertussis, including Tohama, is currently being examined by the radioactivity counting method.

When grown in the $\mathrm{C}$ mode, $B$. pertussis is known to lose many characteristic properties including protective antigen, leukocytosis-promoting factor, heat-labile toxin, adenylate cyclase activity, agglutinogens and certain envelope proteins (Holt and Spasojevic, 1968; Livey, Parton and Wardlaw, 1978; Parton and Durham, 1978; Wardlaw and Parton, 1979; Idigbe, Parton and Wardlaw, 1981). Examination of murine immunoglobulin preparations by immunoblotting suggests that $\mathrm{C}$-mode bacteria also lose their FHA content, as immunoglobulins raised to C-mode W28 cells did not give a detectable response to purified FHA.

The use of the radioactivity counting method in preference to viable counts to study the effects of immunoglobulins on adhesion avoids underestimation of bacterial attachment due to the action of any bacteriostatic antibodies, which, although not preventing adhesion, may hinder colony formation. Treatment of X-mode W 28 cells, which possess FHA and agglutinogens 1, 2 and 3, with immunoglobulins revealed that preparations containing either high levels of anti-FHA or agglutinins 1 and 2 and modest levels of anti-FHA caused marked reductions in bacterial binding. However, immunoglobulin fractions containing antibodies to FHA and agglutinins 1,2 and 3 produced the greatest inhibition of adhesion. Anti-C-mode immunoglobulins which contained antibodies to several OMPs of $B$. pertussis, had very low agglutinating titres and little, if any, anti-FHA and caused only a slight reduction in bacterial attachment. Bacterial agglutination was not detected during the adhesion assay. Therefore, it can be assumed that immunoglobulin preparations which significantly reduced the level of bacterial binding did so by direct interference with the adhesion mechanism rather than by the reduction, due to agglutination, of the number of free bacteria capable of adhering.

There has been uncertainty as to whether the binding ability of $B$. pertussis is directly connected with the presence of certain X-mode specific factors or based on non-specific physicochemical interactions such as hydrophobicity. The cell surface of $\mathrm{X}$-mode bacteria exhibits extreme hydrophobicity which is lost during antigenic modulation (Robinson et al., 1983). The observations presented here together with those of Sato et al. (1981) suggest that the adhesion of B. pertussis to cell surfaces is due to specific mechanisms dependent on the presence of FHA and the agglutinogens. The present assay method employed under appropriate conditions is a useful in-vitro system for assessing the effect of antibody preparations and other substances and treatments on bacterial adhesion.

The author thanks Dr A. Robinson for purified FHA, Miss A. Haynes and Miss M. Melville-Smith for technical assistance and Drs F. W. Sheffield and E. Griffiths for their constructive criticism.

\section{REFERENCES}

Burns K A, Freer J H 1982 Mouse lung adhesion assay for Bordetella pertussis. FEMS Microbiology Letters 13:271-274.

Collier A M, Peterson L P, Baseman J B 1977 Pathogenesis of infection with Bordetella pertussis in hamster tracheal organ culture. Journal of Infectious Diseases 136 Suppl: 196-203.

Evans D G, Perkins F T 1953 An agglutinin-production test in the study of pertussis vaccines. Journal of Pathology and Bacteriology 66:479-488. 
Harboe N, Ingild A 1973 Immunization, isolation of immunoglobulins, estimation of antibody titre. Scandinavian Journal of Immunology 2 (Suppl. 1):161-164.

Holt L B 1972 The pathology and immunology of Bordetella pertussis infection. Journal of Medical Microbiology 5:407-424.

Holt L B, Spasojevic V 1968 The role of surface antigens in the protective potency of Bordetella pertussis suspensions as measured by the intracerebral challenge technique in mice. Journal of Medical Microbiology 1:119-126.

Idigbe E O, Parton R, Wardlaw A C 1981 Rapidity of antigenic modulation of Bordetella pertussis in modified Hornibrook medium. Journal of Medical Microbiology 14:409-418.

Iida T, Ajiki Y, 1974 Growth characteristics of Bordetella pertussis in the chick trachea organ culture. Japanese Journal of Microbiology 18:119-126.

Johnstone A, Thorpe R 1982 Immunochemistry in practice. Blackwell Scientific Publications Ltd, Oxford, pp 184-189.

Keogh E V, North E A 1948 The haemagglutinin of Haemophilus pertussis. I. Haemaggutinin as a protective antigen in experimental murine pertussis. Australian Journal of Experimental Biology and Medical Science 26:315-322.

Livey I, Parton R, Wardlaw A C 1978 Loss of heat-labile toxin from Bordetella pertussis grown in modified Hornibrook medium. FEMS Microbiology Letters 3:203-205.

Lugtenberg B, Meijers J, Peters R, Van Der Hoek P, Van Alphen L 1975 Electrophoretic resolution of the 'major outer membrane protein' of Escherichia coli K 12 into four bands. FEBS Letters 58:254-258.

Marchase R B, Vosbeck K, Roth S 1976 Intercellular adhesive specificity. Biochimica et Biophysica Acta 457:385-415.

Matsuyama T 1977 Resistance of Bordetella pertussis phase I to mucocilliary clearance by rabbit tracheal mucous membrane. Journal of Infectious Diseases 136:609-616.

Morgan J F, Morton H J, Parker R C 1950 Nutrition of animal cells in tissue culture. I. Initial studies on a synthetic medium. Proceedings of the Society for Experimental Biology and Medicine 73:1-8.

Parton R, Durham J P 1978 Loss of adenylate cyclase activity in variants of Bordetella pertussis. FEMS Microbiology Letters 4:287-289.

Parton R, Wardlaw A C 1975 Cell-envelope proteins of Bordetella pertussis. Journal of Medical Microbiology 8:47-57.

Preston N W 1963 Type-specific immunity against whooping-cough. British Medical Journal 2:724-726.

Redhead K 1983 Variability in the surface exposure of the outer membrane proteins of Bordetella pertussis. FEMS Microbiology Letters 17:35-39.

Robinson A, Hawkins D C, Irons L I 1981 The preparation of distinct protective antigens from Bordetella pertussis. FEMS Microbiology Letters 10:241-244.

Robinson A, Gorringe A R, Irons L I, Keevil C W 1983 Antigenic modulation of Bordetella pertussis in continuous culture. FEMS Microbiology Letters 19:105-109.

Sato Y, Izumiya K, Oda M-A, Sato H 1979 Biological significance of Bordetella pertussis fimbriae or hemagglutinin: a possible role of the fimbriae or hemagglutinin for pathogenesis and antibacterial immunity. In: Manclark C R, Hill J C (eds) International symposium on pertussis. US Department of Health, Education and Welfare (DHEW publication no. NIH 79-1830), Washington, D.C., pp 51-57.

Sato Y, Izumiya K, Sato H, Cowell J L, Manclark C R 1981 Role of antibody to leukocytosis-promoting factor hemagglutinin and to filamentous hemagglutinin in immunity to pertussis. Infection and Immunity 31:1223-1231.

Stainer D W, Scholte M J 1970 A simple chemically defined medium for the production of phase I Bordetella pertussis. Journal of General Microbiology 63:211-220.

Vosbeck K, Huber U 1982 An assay for measuring specific adhesion of an Escherichia coli strain to tissue culture cells. European Journal of Clinical Microbiology 1:22-28.

Wardlaw A C, Parton R 1979 Changes in envelope proteins and correlation with biological activities in B. pertussis In: Manclark C R, Hill J C (eds) International symposium on pertussis. US Department of Health, Education and Welfare (DHEW publication no. NIH 79-1830), Washington, D.C., pp 94-98. 